\title{
Diction on The Mother Tongue for Character Building in Early Childhood
}

\author{
Royan Nur Fahmi \\ Guidance and Counseling \\ Universitas Indraprasta PGRI \\ Jakarta, Indonesia \\ royan.nurfahmi@unindra.ac.id
}

\author{
Itsar Bolo Rangka \\ Guidance and Counseling \\ Universitas Indraprasta PGRI \\ Jakarta, Indonesia \\ itsarbolo.rangka@unindra.ac.id
}

isarboloranka amindra acid

Sisca Sisca Folastri

Guidance and Counceling

Universitas Indraprasta PGRI

Jakarta, Indonesia

sisca.folastri@unindra.ac.id

\author{
Fijriani \\ Guidance and Counceling \\ Universitas Indraprasta PGRI \\ Jakarta, Indonesia \\ firjiani@unindra.ac.id
}

\author{
Anna Rufaidah \\ Guidance and Counceling \\ Universitas Indraprasta PGRI \\ Jakarta, Indonesia \\ Anna.rufaidah@unindra.ac.id
}

\begin{abstract}
Character is a distinguishing factor between individuals with one another. Positive characters reflect a positive person, and vice versa. Early childhood is the most important phase in character building efforts. Character formation has several influencing factors, including the parent factor. Parents become a very important factor because through parents is a child at an early age will know, acquire and learn the first language or known as the mother tongue. Through the mother tongue, parents will try to shape the character of his son to be a child with a positive character. The proper use of diction in mother tongue becomes very important because proper selection of words / diction will give precise suggestions. Language has the ability to form the character of the child because the vocabulary contained in the Indonesian language has a positive taste value will cause the impact of positive suggestions, and vice versa.
\end{abstract}

Keywords-mother tongue; character building; early childhood; suggestion

\section{INTRODUCTION}

Human beings as individuals have different characteristics with other human beings[1]. There is a characteristic Difference obtained through several stages in all the way. The stages that play an important role in the development of man is the stage of childhood or a particular period of early childhood development[2].

Early childhood development is a crucial phase of the Child is the milestone of the founding of a nation, because the future of a nation largely determined by the future of children who will be the leader of this country. If the kids are well developed, then they will grow up with the behavior and good character. But if the child's development in many barriers, issues of behavior and character will appear in children. The formation of a person's character and behavior begins the family as the place most early for children to learn, so that through the mother tongue with the use of proper diction characters children at an early age can be well formed[3].

The purpose of writing this article is to give your views on the importance of proper diction in the use of the mother tongue to form the character of early childhood. The author believes that the use of proper diction in the mother tongue can help shape positive characters in early childhood because the mother tongue has a very important position in the process of child development, especially early childhood.

\section{RESUlT AND DISCUSSION}

\section{A. The Diction in Language}

The use of language as a means of communicating in human life has several aspects, one of which is the use of oral language. The use of oral language, said the most important element is in it[4]. The choice of Word or diction becomes very important in the process of communication because through said the message sender or speaker trying to convey the idea or information submitted to the opponent's interlocutor.

The use of the word choice or diction is influenced by the ability of the users of the language associated with knowing, understanding, mastering and using the vocabulary can express ideas precisely so that it can be understood effectively to the listener or the reader in the process of communication[5]. In addition, the effectiveness of communication also requires a number of aspects that must be met by the user language, i.e. the ability to select words that correspond to the demands of communication[6].

There are several terms of the appropriateness of the choice of words: (1) distinguish the meaning denoted and carefully connotation, namely that the word denoted meaning businesslike and not ambiguous. While the connotation may give rise to differing meanings, so that the precision of the word choice is indispensable in the process of communication between the parents with 
children, especially early childhood. (2) the use of words that have a positive meaning for the receiver in the communication process among the parents especially with early childhood, such as the use of the Word no, excuse me, thank you, how are you, good morning. (3) Distinguish the meanings that are almost synonymous. (4) Use the word abstract and concrete words carefully in communicating with early childhood. (5) Using the right pronoun to communicate with early childhood, such as the use of the words I, me, papa, and mama.

In addition to the precision of the word choice, the user's language in this case parents in communicating with early childhood will also need to pay close attention to the appropriateness of words so as not to ruin the meaning, mood, and situations that would like to inflict, or the atmosphere that is being in progress. There are several criteria for the suitability of the words: (1) using a variety of raw carefully and do not confuse its use with words not raw, for example: not (raw), guns (not raw). (2) Use the word related to social values carefully, for instance: pee (PERT), urination/pee (and polite).

Diction or word choice is the spearhead in the communication process, because it is through the word of the idea or the idea of wanting to be conveyed to another person or in this case was early childhood can be carried. There are several functions of the diction in the communication process, including: (1) symbolizes the notion expressed verbally, (2) establish the right idea expression style (very formal, official, unofficial), making fun of the listener or the parties communication are invited in this early childhood, (3) creating communication that is good and right, (4) creates the right atmosphere, (5) prevent differences of interpretation, (6) prevents the wrong understanding, and (7) enables faster achievement of target communication.

\section{B. Mother Tongue}

The language first learned and mastered by children is the mother tongue[7]. The mother tongue of each child is different depending on which language is used by the parent the child in daily life[8]. This affected also by the geographical and social conditions of elderly people[9]. The parents or the mother who comes from a country like Indonesia certainly will use different languages depending on the area where the mother or parents originate. This makes the language used be different every of his son. Although different mother tongue because of the difference of the area, essentially the mother tongue is the language which play an important role in the process of the development of early childhood psychology[10].

Both parents father or mother in the process of the development of early childhood trying to give love best for his son, saying one of its forms through the use of proper words in communication. Communication that is created between the mothers with the child will get the optimal results if the use of the mother tongue of any well used[4].

\section{Character}

The word is derived from the character Greece charassein, meaning to engrave (painting, drawing), as the person who painted paper, carving stone or metal. Rooted from the notion that such character is then interpreted as a sign or special characteristics, and hence bore sutu view that the characters ' behavior patterns that are individual, moral state of a person[7]. Is much more fundamental, i.e. characters enable the conscientious intelligence (SQ)[9]. The characters describe the entire human behaviour, in other words the characters not only limited to certain traits, but rather integrated into a personality. In fact, it could be said that the character is a reflection of values inherent in human beings. Good character is basically the realization of good value is owned by someone.

J. p. Chaplin (1999:82) argued, character is the character or trait that can be formulated in three understanding, namely: (1) the quality or nature of which remains continuous and eternal can be characterized to identify a person. (2) Integration or synthesis of individual properties in the form of one or unity. (3) a person's personality is considered from the point of view of the ethical or moral[10].

As for the factors that are considered to affect the characters in general are: bringing of the factors and environmental factors[10]. The environment where someone lived, is believed to greatly influence the formation of one's character. Environmental factors include family, school, neighborhood and community at large. Family is the first environment experienced by a child. Thus, circumstances, parenting and communication within the family will join in determining how one's character was formed.

\section{Diction in the mother tongue for the character of early childhood Development}

The development of early childhood character was greatly influenced by family environment in this case parents[11]. The parents in the process of educating his son use good language will provide a positive influence for the character of early childhood development, as mother tongue have the ability to give positive suggestion to early childhood[12].

Said as an important part of the language, particularly in the communication process becomes very important to note its use. As with Word, parents attempt to provide information early to early childhood[4]. The selection of the right word will give a positive impact to the child in the digest preliminary information obtained by the child[13].

\section{CONCLUSION}

The development of the child's character is one phase in the process of human development. As the earliest phase, the early childhood development becomes very crucial to the formation of the child's character. An important factor in the development of the character of early childhood is the environmental factor in this case is the family environment.

The family became important in the process of the development of early childhood because the characters in the family occurs the process of early interaction and acceptance of information early in the life of early childhood[14]. So that the use of the mother tongue as the first language a good son is becoming very important to watch out for[4].

Word choice is good and has a positive impression in the use of the mother tongue will provide a positive impact 
also in the process of the development of early childhood character because Word has the ability to give positive autosuggestion auto suggestion or negative[15].

\section{Acknowledgment}

Thanks to Mr. Itsar Bolo Rangka for support so that the author remains confident and wake to begin to know that publication is inevitability

\section{References}

[1] D. Park, E. Tsukayama, G. P. Goodwin, S. Patrick, and A. L. Duckworth, "A tripartite taxonomy of character: Evidence for intrapersonal, interpersonal, and intellectual competencies in children," Contemp. Educ. Psychol., vol. 48, pp. 16-27, 2017.

[2] B. Soediono, "No Title No Title," J. Chem. Inf. Model., vol. 53, no. 1, p. $160,1989$.

[3] K. S. Goodman and Y. M. Goodman, "Mother tongue education: Standard language," 2006.

[4] W. Menninghaus, V. Wagner, E. Wassiliwizky, T. Jacobsen, and C. A. Knoop, "The emotional and aesthetic powers of parallelistic diction," Poetics, 2017.

[5] T. Santoso, "Diksi dan Pola Sintaksis dalam Pepatah Aceh," Humaniora, vol. 19, no. 3, pp. 309-316, 2007.

[6] I. Mulyaningsih, "KOSAKATA YANG DIGUNAKAN ANAK AGRESIF DI PENDIDIKAN ANAK USIA DINI (PAUD) SEKOTA CIREBON," Holistik, vol. 1, no. 2, pp. 191-204, 2016.
[7] M. Tomasello and M. J. Farrar, "Joint attention and early language," Child Dev., pp. 1454-1463, 1986.

[8] R. Wildova and J. Kropáčková, "Early childhood pre-reading literacy development," Procedia-Social Behav. Sci., vol. 191, pp. 878-883, 2015.

[9] K. Kohnert, "Bilingual children with primary language impairment: Issues, evidence and implications for clinical actions," J. Commun. Disord., vol. 43, no. 6, pp. 456-473, 2010.

[10] L. A. G. Senna, "Culture and Society in the Teaching of the Mother Tongue and Literature," Procedia-Social Behav. Sci., vol. 178, pp. 123-127, 2015.

[11] F. Rokhman, M. Hum, and A. Syaifudin, "Character Education For Golden Generation 2045 (National Character Building for Indonesian Golden Years)," Procedia-Social Behav. Sci., vol. 141, pp. 1161-1165, 2014.

[12] H. F. Rasmussen et al., "Mother-child language style matching predicts children's and mothers' emotion reactivity," Behav. Brain Res., vol. 325, pp. 203-213, 2017.

[13] C. Hutton, "Who owns language? Mother tongues as intellectual property and the conceptualization of human linguistic diversity," Lang. Sci., vol. 32, no. 6, pp. 638-647, 2010.

[14] N. Love and U. Ansaldo, "The native speaker and the mother tongue," Lang. Sci., vol. 32, no. 6, pp. 589-593, 2010.

[15] J. Peng, L. Mo, P. Huang, and Y. Zhou, "The effects of working memory training on improving fluid intelligence of children during early childhood," Cogn. Dev., vol. 43, pp. 224-234, 2017. 